See discussions, stats, and author profiles for this publication at: https://www.researchgate.net/publication/326928635

\title{
Buku Ajar Pelatihan Parenting
}

Book · March 2018

\section{CITATIONS}

2 authors, including:

(2) Ismaniar Ismaniar

Situs Resmi Universitas Negeri Padang

7 PUBLICATIONS O CITATIONS

SEE PROFILE

Some of the authors of this publication are also working on these related projects:

READS

177

Project MODEL PERMAINAN ESTAFET BAIT LAGU UNTUK MENINGKATKAN KEMAMPUAN PEMUSATAN PERHATIAN PADA ANAK View Project 


\section{BUKU AJAR \\ PELATIHAN PARENTING}

\section{ISMANIAR \\ VEVI SUNARTI}

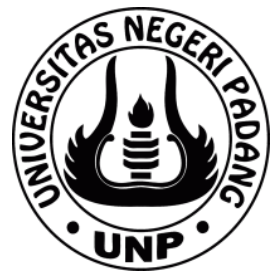

Penerbit

Jurusan Pendidikan Luar Sekolah

Fakultas Ilmu Pendidikan

Universitas Negeri Padang 


\section{Sanksi Pelanggaran Pasal 72:}

\section{Undang-Undang Nomor 19 Tahun 2002 tentang Hak Cipta}

1. Barangsiapa dengan sengaja dan tanpa hak melakukan perbuatan sebagaimana dimaksud dalam Pasal 2 ayat (1) atau Pasal 49 ayat (1) dan ayat (2) dipidana dengan pidana penjara masing-masing paling singkat 1 (satu) bulan dan/atau denda paling sedikit Rp1.000.000,00 (satu juta rupiah), atau pidana penjara paling lama 7 (tujuh) tahun dan/atau denda paling banyak Rp5.000.000.000,00 (lima miliar rupiah).

2. Barangsiapa dengan sengaja menyiarkan, memamerkan, mengedarkan, atau menjual kepada umum suatu Ciptaan atau barang hasil pelanggaran Hak Cipta atau Hak terkait sebagaimana dimaksud pada ayat (1) dipidana dengan pidana penjara paling lama 5 (lima) tahun dan/atau denda paling banyak Rp500.000.000,00 (lima ratus juta rupiah). 


\section{BUKU AJAR \\ PELATIHAN PARENTING}

\section{ISMANIAR \\ VEVI SUNARTI}

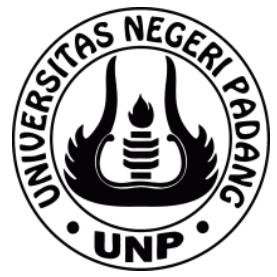

Penerbit

Jurusan Pendidikan Luar Sekolah

Fakultas Ilmu Pendidikan

Universitas Negeri Padang 
Penerbit Jurusan Pendidikan Luar Sekolah

Fakultas Ilmu Pendidikan Universitas Negeri Padang

Padang, Sumatera Barat

Indonesia

Judul:

BUKU AJAR PELATIHAN PARENTING

Penulis : Ismaniar \& Vevi Sunarti

Editor : Alim Harun Pamungkas

Desain : Wendi Ahmad Wahyudi

Copyright@2018

by Penerbit Jurusan Pendidikan Luar Sekolah

Fakultas Ilmu Pendidikan Universitas Negeri Padang

Padang, Sumatera Barat

Pertama kali diterbitkan dalam Bahasa Indonesia

Oleh Penerbit Jurusan Pendidikan Luar Sekolah

Fakultas Ilmu Pendidikan Universitas Negeri Padang

Cetakan pertama: Maret 2018

ISBN: 978-602-60486-6-0

Hak cipta dilindungi undang-undang.

Dilarang memperbanyak sebagian atau seluruh isi buku ini tanpa izin tertulis dari

Penerbit 


\section{PRAKATA}

Duji dan syukur kepada Allah SWT atas rahmat dan karunia-Nya, sehingga kami 1 dari Tim Pelaksana pengabdian kepada masyarakat Universitas Negeri Padang telah dapat membuat "Buku Ajar" untuk kegiatan pengabdian yang berjudul "Pelatihan Parenting bagi Orang Tua Anak Usia Dini di Kelurahan Air Tawar Barat Kecamatan Padang Utara Kota Padang"

Kegiatan ini merupakan salah satu wujud tugas kami sebagai dosen dalam melaksanakan Tri Dharma Perguruan Tinggi. Terlaksananya kegiatan pengabdian ini dengan sukses dan lancar berkat kerjasama tim yang baik. Di samping itu kesuksesan pelaksanaan kegiatan pengabdian ini juga tidak lepas dari bantuan dan dukungan dari berbagai pihak.

Ucapan terima kasih dan penghargaan atas kesempatan dan dukungan yang diberikan kepada tim, khususnya kepada;

1. Dr. Alwen bentri, M.Pd. Dekan Fakultas Ilmu Pendidikan Universitas Negeri Padang.

2. Dra. Wirdatul'Aini, M.Pd. Ketua Jurusan Pendidikan Luar Sekolah Fakultas Ilmu Pendidikan Universitas Negeri Padang.

3. Prof. Dr. Rusdinal, M.Pd. Ketua Lembaga Penelitian dan Pengabdian kepada Masyarakat Universitas Negeri Padang.

4. Eva Suryani, BE, S.Pd. Ketua PKBM Anarvani Kelurahan Air Tawar Barat Kecamatan Padang Utara Kota Padang.

5. Nana Ernawati Arwin, S.Pdi. Kepala PAUD Arraudhah Kelurahan Air Tawar Barat Kecamatan Padang Utara Kota Padang. 
6. Orang tua anak usia dini di Kelurahan Aira Tawar Barat dan sekitarnya yang telah mengikuti kegiatan pelatihan dengan penuh semangat dan berusaha untuk selalu tepat waktu selama kegiatan berlangsung.

Kami mengucapkan permohonan maaf kepada semua pihak jika terdapat kekurangsempurnaan dalam penulisan laporan ini. Semoga laporan ini senantiasa ada manfaatnya bagi semua pihak.

Padang, Agustus 2017

Tim pelaksana 


\section{DAFTAR ISI}

PRAKATA

BAB I

Pendahuluan

\section{BAB II}

Konsep Dasar Parenting 3

A. Tujuan Pembelajaran 3

B. Materi Pembelajaran 3

1. Pengertian Parenting 3

2. Tujuan Parenting 5

3. Kesadaran Parenting/Pengasuhan 5

\section{BAB III}

Tugas, Fungsi Dan Tanggung Jawab Keluarga 7

A. Tujuan Pembelajaran $\quad 7$

B. Materi Pembelajaran $\quad 7$

1. Pengertian Keluarga 7

2. Tugas/Fungsi Keluarga 8

\section{BAB IV}

Pentingnya Pendidikan Anak Usia Dini $\quad 10$

A. Tujuan Pembelajaran 10

B. Materi Pembelajaran 10

1. Hakikat Anak Usia Dini 10

2. Hakikat Pendidikan Anak Usia Dini 11

3. Pentingnya Pendidikan Anak Usia Dini 11 


\section{BAB V}

Bahaya Anak Kurang Perhatian Dan Pengawasan Orang Tua 13

$\begin{array}{ll}\text { A. Tujuan Pembelajaran } & 13\end{array}$

B. Materi Pembelajaran 13

1. Pentingnya Perhatian dan Pengawasan Bagi Anak Usia Dini 13

2. Bahaya-bahaya yang Terjadi Jika Anak Kurang Perhatian dan Pengawasan 15

BAB VI

Metode dan Media Pengembangan Potensi AUD 17

$\begin{array}{ll}\text { A. Tujuan Pembelajaran } & 17\end{array}$

B. Materi Pembelajaran 17

1. Mengenal Membaca Permulaan 17

2. Media Permainan Edukatif 18

$\begin{array}{lr}\text { DAFTAR PUSTAKA } & 20\end{array}$

LAMPIRAN $\quad 22$

TENTANG PENULIS $\quad 28$ 


\section{BAB I Pendahuluan}

$\mathrm{M}$ asa usia dini merupakan periode yang sangat penting bagi perkembangan dan pertumbuhan setiap individu manusia. Berbagai keunikan terjadi selama proses pertumbuhan dan perkembangan setiap anak, dan meliputi berbagai aspek perkembangan baik perkembangan keterampilan motorik, kognitif, afektif, bahasa dan lain sebagainya. Di berbagai sumber dijelaskan bahwa karena sedemikian pentingnya masa usia dini, sehingga sering disebut sebagai Golden Age, yaitu masa pertumbuhan yang sangat hebat dan sensitif terhadap setiap stimulasi yang diberikan.

Begitu penting dan sangat menentukannya pertumbuhan dan perkembangan pada masa usia dini, maka perlu mendapat perhatian dari semua pihak. Pemberian stimulasi pada anak usia dini perlu dilakukan secara seksama dan melibatkan semua pihak. Hal ini sesuai dengan pendapat yang dikemukakan Mansur (2011) bahwa dibutuhkan pendekatan yang akan digunakan dalam kegiatan pembelajaran yang memusatkan perhatian kepada anak. Keterlibatan dari lingkungan keluarga, sekolah dan masyarakat secara bersama-sama anak mendatangkan hasil yang lebih optimal.

Masing-masing lingkungan pendidikan memiliki peran yang sangat penting dan tentunya dengan karakter masing-masing pula. Di antara ketiga lingkungan tersebut lingkungan keluarga merupakan lingkungan pertama dan utama. Dikatakan lingkungan pertama karena memang secara faktanya hampir semua anak yang terlahir ke dunia ini mendapati keluargalah yang menyambut mereka dan memberikan layanan yang mereka butuhkan di awal kehidupannya. Sementara dikatakan sebagai lingkungan yang utama karena fakta juga menunjukkan bahwa semua kemampuan dasar yang dimiliki oleh setiap anak dalam kehidupannya baik 
pengetahuan, keterampilan maupun sikap yang diperlukan dalam kehidupan mereka peroleh dalam keluarga. Jika keluarga berhasil menanamkan pengetahuan, keterampilan dan sikap dasar bagi anak-anaknya maka setiap anak akan berhasil memasuki lingkungan yang kedua, ketiga dan lebih luas lagi. Sebaliknya jika keluarga gagal menanamkan pengetahuan, keterampilan dan sikap dasar pada anaknya sejak usia dini maka anak akan mengalami berbagai hambatan dalam pertumbuhan dan perkembangan pada periode selanjutnya dan kesulitan untuk masuk ke lingkungan yang lebih luas.

Berdasarkan uraian di atas terlihat bahwa seyogyanya setiap keluarga memiliki pengetahuan dan keterampilan yang cukup tentang berbagai hal yang dapat diperhatikan dan dilakukannya terkait dengan upaya mendukung pertumbuhan dan perkembangan yang optimal bagi anaknya. Seiring perkembangan ilmu pengetahuan dan teknologi, banyak hal yang harus berubah, termasuk dalam memberikan layanan bagi anak usia dini. Orang tua tidak bisa hanya mengandalkan insting dan menirukan kembali cara-cara yang dilakukan oleh orang tua mereka dulu ketika mendidik mereka. Berbagai pengetahuan dan keterampilan perlu dipelajari oleh orang tua anak usia dini dalam mendidik anaknya pada zaman sekarang yang sarat dengan berbagai tantangan.

Salah satu cara yang dapat dilakukan untuk meningkatkan pengetahuan dan keterampilan orang tua dalam mendidik anak dapat dilakukan dengan mengikuti program parenting. Pada bahan ajar ini penulis akan membahas berbagai hal mengenai program parenting. 